\title{
TACTICAL ASPECTS REFERRING TO THE MILITARY REGULATIONS OF THE ROMANIAN AND SOVIET INFANTRY AROUND THE BEGINNING OF THE WORLD WAR II
}

\author{
Ionel HALIP \\ "Ştefan cel Mare" University, Suceava, Romania \\ halip.ionel18@yahoo.com
}

\begin{abstract}
In this article, a comparison study was done on the tactical principles of the Romanian infantry and the Soviet one around the beginning of the Second World War, in the context of developing and perfecting the weaponry. In order to reach this objective, there was an analysis of the regulations of the infantry emerged after the end of the First World War, emphasizing the differences and the parallels in tactical norms for the battalion and the infantry regiment. Likewise, the differences concerning the wording, content, appendices and the mission report are presented in an order of operations between the two armies. Having considered that during the Eastern Campaign, the Romanian army had suffered human losses due to the cold and lack of protection equipment, it was analyzed whether the Romanian regulations had foreseen protective measurements during winter time. At the same time, the article presents the operations during winter envisioned in the Soviet regulation, both for offense and defense, and also the measures that had to be taken in order to prevent frostbite.
\end{abstract}

KEYWORDS: tactics, infantry, military regulation, soviet, order of operations

\section{Introduction}

The military tactics that sprung with the first violent clashes in primitive society, had rapidly evolved in the modern era due to the economic progress of the armies. The $20^{\text {th }}$ century - from its beginning to the end of the Second World War - makes the most powerful variation of tactics (Arsenie, Marinescu, Cojan, Cristea, Rus \& Bădălan, 1986).

Up until 1930 the principles of the Romanian infantry tactics have reflected, not only the lessons learned in the First World War, but also the level of experience acquired during training and battle. In 1930 the Temporary regulation for infantry training were edited - the second part - the combat, and so were the Temporary instructions on tactical usage of large units (Şuţa, 1982, p. 187). With all this, around the beginning of World War II, the regulations were incompatible because a large number of training departments of the infantry were treated in separate regulations. Taking this into consideration, there were adopted in 1939 the Temporary regulation for C. 4 infantry combat, and, on the basis of Decree no 4443/1939 of 25th of January 1940 the Temporary regulation on the technical training of the infantry C.3, the Romanian army entered the Second World War. Regulation C.3 was organized in three volumes with the following contents: Volume I (the soldier, rifles subunits and research company), Volume II (machine guns, anti-tank guns, throwers, heavy 
equipment subunits and research company) and Volume III (the battalion, regiment and brigade tactics) (Ministry of National Defence, 1940, p. 5).

In the Soviet army, the principles of combat for the infantry were featured in the Temporary regulation on serving the campaign for the Red Army in 1936. This Regulation was implemented starting with the $30^{\text {th }}$ of December 1936 revoking the one from 1929 through an order signed by the Comisar of Defense of USSR, marshal Kliment Voroșilov. An important aspect of this new regulation was the fact that, unlike the previous ones it didn't offer templates, leaving up to the commanders to make decisions according to the situations on the battle field (Romanian General Staff, 1937). The Regulation was structured in 13 chapters focusing strongly on assuring the material needs for the operations (chapter III) and for the logistics by satisfying "the troupes' needs on time and continuously with everything that is necessary" (Ministry of Defence, 1937, art. 75).

\subsection{Research Methodology}

This article's main focus is on the comparative analysis of the tactical principles of the Romanian and the Soviet regulations around the beginning of the World War II. The research began with the following hypothesis: the existence of differences between tactical principles of the battalion and of the infantry regiment; the orders of operations, both from an editing point of view and the content between the two armies; and the differences between the regulations of the Romanian infantry and the Soviet one referring to the battle during winter time.

The research was completed by studying the regulations of that time, the documents available at the national military archives in Pitești, the editorials: "General Staff, Section 5 Training, Bureau 3 Regulations, file no. 561 B, The Regulation of the soviet campaign service", "Inventory no. R1779 from 1981, year 1940, file no 388 , The temporary regulation for technical training of the infantry C3", "Rijo - 1, Journal of operations - The $16^{\text {th }}$ Dorobanti Regiment file no. 3366", and specialty literature.

2. The Differences between the Soviet and the Romanian Infantry's Order of Operations

For the comparative analysis of the two orders of operations, were taken into consideration the following: the order of operations no. 10 of the $16^{\text {th }}$ Dorobanti Regiment, from the $5^{\text {th }}$ of October 1939 for the Romanian order, and for the Soviet one, the regulation of the campaign service which stipulated both the editing and the content of the order. In editing the document, great attention was paid, in the case of both armies, to the clear and precise wording of the general mission in order to express firmly the decision that was made to achieve the intended purpose.

An order of operations for the $16^{\text {th }}$ Dorobanți Regiment, concerning the World War II was composed of two parts. The first one consisted of 13 chapters structured as follows: 1 - The situation, which presented the disposition of enemy and friendly forces, 2 - The mission, 3 - The action area (limitations of action), 4 - The defense / attack plan, 5 - The safety positions, 6 - The order of battle (presented on echelons, reserve, and also tactical connections), 7 - Fire plan, 8 - Cooperation with the artillery, 9 - Anti-tank defense, 10 - Military engineering, 11 - Destructions, 12 - Communications and transmissions. At the end of the order there were also presented the indicatives of units and subunits (Ministry of National Defence, 1939). The second part presented aspects referring to logistics as follows: 1 - Food, 2 - Resupplies, 3 - Sanitary service, 4 - Ammunition, 5 - Postal service.

The Soviet regulations' first chapter renders briefly the operations' characteristic 
and the general formation of the enemy. In the second one, the missions of the neighboring units and the separation limits were presented, and in the next chapter the general idea of maneuver for the units and the missions resulted from it for the subordinated units was formulated, by listing additional means distributed. Likewise, in the same chapter the mission for the artillery, tanks and chemical units (it was missing in the order of operations for the $16^{\text {th }}$ Dorobanți Regiment) was presented. In the fourth chapter the initial command post was established and its direction of movement. In the last chapter the area of contact for supplies was specified (Ministry of Defence, 1937, art. 128).

In both cases, the mission and the appendices for the order of operations was established by the General Staff of the unit, with differences regarding structure. Unlike the Romanian order of operations, which showed the mission of the superior echelon, in the Soviet ones it was forbidden to show the mission of the superior echelon. In the last regulation mentioned, it was done verbally or rarely in writing and only to a small number of soldiers, having it destroyed immediately after taking notice of it (in a division's order the mission of the army corps was not presented or in the regiment's order the division's mission was not presented, an aspect that proved to be a success factor for preventing information leakage).

On the other hand, the commanders of the battalion's superior echelons were given written orders, and to the commanders of the battalion verbal orders. For reconaissance, communication, antiaircraft defense, anti-tank, and against gas weapons, there were given special orders (Ministry of Defence, 1937, art. 128). For the sake of completing the order of operations, a chart like a plan of the attack was attached and it indicated: the estimated hours for reading different objectives by the tanks and the infantry, the distribution and decentralization of the artillery during battle, the signals for cooperation between tanks, infantry, artillery and aviation (Ministry of Defence, 1937, art. 129).

Thus, based on the above, it is obvious that the Soviet order of operations was completed by also presenting the chemical units' mission, an aspect that the Romanian order of operations did not provide (for example the signals used for collaboration between tanks, infantry, artillery and aviation).

\section{Battle Principles during Winter Time in the Soviet Regulation}

Unlike the Romanian regulations, the Soviet ones concerning the World War II, were handling, very concisely, the battle during winter time by presenting the recon report, march characteristics, offensive battle conditions, achievement of defense and ways to combat frostbites.

A separate chapter in the Soviet regulation embodied the operations during winter, emphasising not only the importance of towns regarding the troupes' quartering and resting, but also the number of marches and night operations. The troupes' mobility and capacity for maneuver was entirely depended on the level of training, the supply of necessary means for winter actions and on the character of the theater of operations, the necessary means to complete missions being provided in the regulation (Romanian General Staff, 1937, p. 200).

In organizing the march, terrestrial and aerial recons were done in order to establish the existence and accessibility of winter roads. The march was calculated in relation to winter specific conditions, and usually it lasted for about 7 hours. It was necessary that the marching stage finished in towns, forests or areas shielded from the wind and to ensure the supply with fuel. The strength and composition of the convoy was calculated so that it can function independently. During the march, recons 
were done by skiers, tanks and vehicles that could get through any terrain, and the safety service was done by skiers. The roads were opened through pounding by military engineers (Ministry of Defence, 1937, art. 273).

In snow, the attacks were held alongside roads. At night, the attacks were led by squads of skiers to destroy the advancing enemy units. During the day in the open field and in deep snow, the approaching and deploying of the infantry was done on skis at the shelter of smokescreens. It was taken into account the changing of the tactical proprieties for the local objectives (water courses, lakes swamps, forests, bushes, etc.) in order to use them as shelters. The artillery had to be mounted on skis as the attack was unfolding, and the tanks were participating in battle only when the snow's depth was below $30 \mathrm{~cm}$ (Romanian General Staff, 1937, p. 202).

In winter, defense had to take place near towns. The regulation forbade the possibility for the enemy to use towns and forests to establish a temporary position of resistance. The exterior limit for the position of resistance was chosen to be behind areas of ground that were difficult to get through during winter by the infantry and combat vehicles (ravines, heavy snow, water courses, creeks with thin ice etc.). The telephone connection was established by skiers through slates. As gas weapons were more persistent during winter, the regulation provided further defensive measures against them. In order to preserve the strength and combat ability of the staff, if the situation allowed it, the troupes' resting period by day and night took place in buildings. When the troupes held the position of resistance, underground hovels were built. Measures to prevent frostbites were taken: the timely distribution of warm equipment, the distribution of lotions for specific parts of the body that were exposed to the cold and the drying of items (Ministry of Defence, 1937, art. 279).

\section{The Tactical Norms of the Infantry Battalion}

The infantry battalion represents the combat unit capable of fighting both in offensive and defensive, it has in its organization means for fire, movement and impact, and it is considered the fundamental tactical unit in weapon cooperation (Ministry of National Defence, 1940, art. 1). For approach formations, the front of the battalion was of $1000-1200 \mathrm{~m}$, and the depth of 1200-2000 m, varying as follows: when the battalion was acting as the vanguard, the intervals and distances between companies were larger (the interval could have been of 300-400 $\mathrm{m}$ and the distance of 500-600 m); when the battalion was behind the convoy, the intervals and distances between companies were shrinking up to 100 - 200 m (Ministry of National Defence, 1940 , p. 23). In battle, usually the infantry battalion was arranged on two echelons leaving the general to decide the arrangement of the companies on each echelon, the distances and intervals between them according to the mission, the terrain and the enemy's resistance (Ministry of National Defence, 1940, art. 14). In defence both the front and the depth formations were greater than in attack, reaching $1500 \mathrm{~m}$, the battalion consisting of two companies of riflemen in the first echelon and a company in the second one (Ministry of National Defence, 1940, p. 29).

Unlike the Romanian infantry's tactic, the Soviet army's infantry battalion's tactic mapped out the length of the attack battalion's front up to maximum of $600 \mathrm{~m}$. In case a battalion had more artillery or combat vehicles, the attack front could be expanded up to $1000 \mathrm{~m}$. For the main effort there were assigned superior means and forces. The width of the attack front was conditioned by the quantity of means of destruction available, the characteristics of 
the terrain, the degree of development and anti-tank defence and the nature of the enemy fortification. When an enemy was attacked, one that recently went into defensive, an infantry battalion from the first echelon of the impact group was backed up by an artillery squadron and a company of combat vehicles (Ministry of Defence, 1937, art. 175).

At the same time, the attack plan, both for attacking the enemy flank, and for frontal attack, didn't have to aim for the rejection of the enemy troupes, but to circle them and capture war materials. The most important condition for the success of the attack was taking the enemy by surprise, therefore all the preparations were done in secret (Ministry of Defence, 1937, art. 172).

\section{The Tactical Norms of the Infantry Regiment}

The regiment represented the tactical unit where the entire weaponry for the infantry was used, and it consisted of: an army commander, a general staff, a command company, a reconnaissance company newly implemented in the infantry's tactic, a company of regimental heavy weapons, three identical battalions, a combat train and a regimental train (Ministry of National Defence, 1940, art. 24).

The front and the depth of the regiment's approach formations, as the corresponding intervals and distances between battalions varied as follows: when the regiment was at the front line of a division, the front would vary between 3-5 km (the intervals between battalions were of $1-2 \mathrm{~km}$ and the depth from 4 to $6 \mathrm{~km}$ ); when the regiment was at the second line of a division or it was part of a second line division, the front and depth of approach formations would vary between $3-4 \mathrm{~km}$ (the intervals and distances between battalions being in this case from $500-1000 \mathrm{~m}$ ) (Ministry of National Defence, 1940, p. 35).
Within these regulations there were specified the cooperation between infantry and artillery, cavalry, military engineering, chemical means and aviation. It also provided the infantry's battle elements considered as permanent: battle against armored vehicles, research, observation, anti-aircraft defense, protection against gases, camouflage, transmissions, information, safety and surprise attacks (Ministry of National Defence, 1940, p. 28). Among the ones listed above, a permanent character was given for the first time to: anti-aircraft defense, protection against gases and battle against armored vehicles. However, at that time, there were only a few tanks in the Romanian army, their usage against armored vehicles was unlikely, nevertheless solutions were sought in order to assure the efficiency of the infantry battle with these means (Şuţa, 1982, p. 190).

Unlike the Romanian infantry regiment's tactic, the Soviet one concerning the beginning of The World War II, presented succinctly the cooperation between aviation, artillery and tanks. Therefore, the Soviet regulation stipulated that during an offensive, the attack could be preceded by approaching from a great distance, being able to begin right from a position of contact with the enemy or against an enemy that went into defense during an encounter combat (Ministry of Defence, 1937, art. 162).

The troupes were acting in battle and march formations. The march formation allowed for immediate deployment in order to put together a most advantageous group of forces and the possibility to reject air strikes. This was organised in many convoys from the force's entirety and from the service units for marching safety. The battle formation consisted of one impact group and one support group; by instalment in depth (two - three echelons), the last one secured the continuity of the depth maneuver. The marching and battle formation took safety measures also for anti-aircraft 
defense, against gas weapons and anti-tank (Ministry of Defence, 1937, art. 106).

The infantry regiment had the impact group divided into two echelons. When the attack sector was narrow, the regiment arranged battalions in three echelons. The missions of the first two were to get involved in the battle on the first flank, attacking the enemy and determining the result in battle. During offensive battle, tanks completed the artillery's shootings, having the task of destroying enemy antitank vehicles (Romanian General Staff, 1937, p. 141).

After taking a battle formation, the infantry gathered through leaps and crawled in position where it was announced the assault against the enemy. The attack was carried with gas masks on hold and a special mantle in the backpack with one corner sticking out. When the enemy battle aviation was attacking, all fighters would put on their gas masks and special mantles and continue the mission. The fighters affected by the persisting war gases coming from the aircraft or those who came into contact with infected terrain used anti-gas packages. The first echelon's mission was to conquer the enemy position being backed up by the second echelon. Throughout all this time, the tanks for remote actions and also those of direct support acted continuously until the circling and destruction of the enemy (Romanian General Staff, 1937, p. 152).

The Soviet regulation presented succinctly the way a contact battle should progress, with the recommendation of it being developed right from the march formation in motion toward the enemy, situations that usually took place in various way. The insufficient information on the real formation of the enemy was a regular phenomenon in the contact battle. The aim of this battle was surrounding and destroying the enemy by all means, for battle working together (Romanian General Staff, 1937, pp. 110-111).
The enemy had to be out of gear before engaging in encounter battle. The disarrangement of the enemy's march was achieved firstly through the action of the aviation. The aerial attack on enemy formations prepared the destruction operation of the enemy by fractions. The maximum effect was achieved by the aviation through machine-guns, bombardment and launching war gases. The aviation's action had to be pointed at enemy personnel, artillery, artillery park and means of transportation (Ministry of Defence, 1937, art. 144).

An important role was held by recon, out of which the aerial one took central stage. Terrestrial recon was executed by recon battalions of divisions, organized before beginning the march and had the task of uncovering enemy troupes. The recon parties were fitted with means for rapid transmission in order to send reports, and at the same time, they took measures against interception of phone calls by the enemy (Romanian General Staff, 1937, p. 117).

\section{Conclusions}

In this article, the hypothesis that started the research was verified and confirmed. Referring to the tactical norms of the infantry battalion, there were differences between the two armies. The front of a Soviet attack battalion was smaller $(600 \mathrm{~m})$ in comparison to the Romanian one, which could reach up to $1200 \mathrm{~m}$ and was less equipped with artillery or tanks. A resemblance constitutes the fact that the front could have been widened based on the technique and the terrain. Concerning the regiment, the Romanian tactical norms stipulated predetermined intervals and distances, and the Soviet regulations did not provide templates, but they left it up to the generals to decide the layout. If the Romanian tactic barely mentioned the concept of weapons cooperating, the Soviet tactic presented 
succinctly the way for the aviation, artillery and tanks to cooperate.

Both the Romanian and Soviet military regulations paid a close attention to the order of operations, especially regarding the wording of the mission and it was done in both cases by the military unit's general staff. The Soviet regulation presented the mission of the chemical subunits, an aspect that was not found in the Romanian order of operations. At the same time, a strong point represented the fact that in the Soviet order of operations it was forbidden to show the mission to the superior echelon, and this action was done only verbally to a small number of military.

Although the Romanian army had paid great attention to the battle in the mountains, the Romanian infantry regulations did not foresee aspects referring to battle during winter time, a fact that will cause significant loses during the eastern front campaign. On the other hand, the Soviet regulation covered very concisely the principles of battle during winter, being much more complete and detailed than the Romanian ones.

\section{REFERENCES}

Arsenie, V., Marinescu, T.R., Cojan, V., Cristea, I., Rus, I., \& Bădălan, E., (1986). Tactica în războiul întregului popor pentru apărarea patriei. Bucharest: Editura Militară.

General Inspectorate of Infantry. (1940). Regulamentul provizoriu asupra instrucției tehnice a infanteriei. Vol. III, C.3, Bucharest: Editura „Bucovina” I. E. Torouțiu.

Ministry of Defence. (1937). Regulamentul provizoriu asupra serviciului în campanie al Armatei Roşii (P.U.-36). Moscow: Editura Militară de Stat a Comisariatului Apărării Ţării.

Ministry of National Defence. (1939). Journal of operations - The $16^{\text {th }}$ Dorobanți Regiment Inventory. no. 3366, Military archives of Piteşti.

Ministry of National Defence. (1939). The temporary regulation for C.4 infantry combat. Military archives of Piteşti.

Ministry of National Defence. (1940). The temporary regulation on the technical training of the infantry C.3., Inventory no. R. 1779/1981, file no. 388, Military archives of Piteşti.

Romanian General Staff. (1937). Regulamentul provizoriu asupra serviciului $\hat{\imath}$ campanie al Armatei Roşii. Inventory no. S96/16.08.1972, file no. 561 B, Military archives of Piteşti, Section 5.

Şuţa, I. (1982). Infanteria română de la primul război mondial până în zilele noastre. Vol II, Bucharest: Editura Militară. 